\title{
Bedřich Smetana: An Artist and a Man of His Times
}

\section{Olga Mojžíšová}

In the early 1860s, Bedřich Smetana returned to his homeland permanently after having spent five years abroad. This happened just as a new era was beginning, a period full of enthusiasm, hopes, and plans for the advancement of Czech society and its culture under conditions of greater freedom. However, especially in the sphere of culture, there were still considerable limitations. In order for Czech musical life to function and develop, there was a need to create essential supporting institutional structures and to continue with the cultivation of the Czech public. At the time, domestic artistic production was still neither plentiful nor well defined. Like many of his contemporaries, Smetana engaged himself with great hopes and plans, but in realising them he had to deal with operational and financial possibilities that did not remotely meet his ideas and intentions. Like others, he also had to deal with the prosaic problems of everyday life, earn a living, and provide for his family, something that was far from easy for artists under the prevailing circumstances.

When Smetana's five years of activity in the Swedish city Göteborg (Gothenburg) ended in 1861, he left behind his well placed social and economic standing without having secured any way of earning a living in his homeland. Before his departure for Sweden, his only source of income had been teaching, ${ }^{1}$ and he took advantage of occasional opportunities in Prague's concert life. It was in Göteborg that he was first able to engage himself fully as a concert artist-as a pianist and in chamber music and newly as a choirmaster and conductor as well. There, he was also primarily a music teacher-as he had done in Prague, he operated a musical institute and had numerous private clients. At the same time, he was the director (i.e., choirmaster) of the vocal section of the amateur musical society Harmoniska sällskapets with which he was able to rehearse and perform a number of important works for voices and instruments, including music ranging from the Baroque era to contemporary works by composers for

1 From 1848 to 1856 he operated a musical institute in Prague, and he was teaching privately at the same time. For more information, see Olga Mojžíšová, "Die finazielle Lage Bedřich Smetanas in Lichte der Quellen,” Musicologica Olomucensia 27 (2018): 16-18, 37. 
whose music he had an affinity. He also took the initiative in the creation of regular subscription series of chamber concerts, and he had many more concert opportunities as a solo pianist. In spite of the provinciality and quasi-amateurism of Göteborg's musical life and the limited possibilities for musical productions, ${ }^{2}$ he introduced a number of new impulses, such as different repertoire, new forms of concert life, and musical instruction of better quality. He also gave a new programmatic dimension to his works in the realms of piano and orchestral music. ${ }^{3}$ While all of this was taking place, he was widely popular and respected in society, and his financial situation was very good-income from pupils, usually from Göteborg's wealthiest circles, supplemented his salary as director of the music society and fees for certain concerts. ${ }^{4}$ Artistically and financially, this was vastly different from his earlier period in Prague (1847-1856) where he had earned a good reputation, made a decent living as a music teacher, and won respect and recognition in musical circles as a pianist and chamber musician, but where he had not had a chance to give concerts of a higher profile or otherwise to exert much influence on Prague's musical life. Smetana returned from Göteborg to Prague as a mature, confident artist with freshly acquired practical experience, broad artistic perspectives, and well-formed opinions, but with nothing more than the hope of capitalising on that potential in his homeland.

The thaw of the political situation in the Austrian monarchy in the early 1860s led to a revival of societal and cultural life in Bohemia, and in connection therewith came relatively quick growth of the activity of associations and the creation of some new Czech musical institutions which played an important role in this process. The founding of the Prague singing society Hlahol in 1861 influenced the rapid flourishing of a choral movement in Bohemia, the opening of the Provisional Theatre in 1862, the first full-time Czech professional stage with its own drama and opera ensembles, was a powerful stimulus for the advancement of Czech opera composing, and the Artists' Society (Umělecká beseda), created in 1863, brought together Czech visual artists, authors, and musicians. Culture

2 Professional musical institutions were lacking there, and especially a permanent opera stage and orchestra.

3 In Göteborg from 1858 to 1861 he wrote his first three symphonic poems: Richard III, Wallensteins Lager, and Hakon Jarl. Some of his piano compositions also reflect programmatic inspiration and the search for new expressive possibilities. This was a reflection in particular of Smetana's encounter with Franz Liszt in Prague (1856) and during visits to Weimar $(1857,1859)$.

4 For more information about Smetana's activities in Göteborg, see Olga Mojžíšová, "Smetanův Händel, Haydn a Mendelssohn v Göteborgu," in Miscellanea z výročni konference České společnosti pro hudebni vědu 2009 (Praha: Agora, 2012), 130-139; Mojžíšová, "Die finanzielle Lage," 19-20, 38; Olga Mojžíšová and Milan Pospíšil, Bedrich Smetana Correspondence I 1840-1862 (Praha: Národní muzeum, KLP, 2016), *79-*82, 75-269; Anders Carlsson, Handel och Bacchus eller Händel och Bach? (Göteborg: Tre Böcker Förlag AB, 1996), 207-235. 
and the arts, music included, became an important manifestation of efforts towards national emancipation and, at the same time, a means of representation of Czech society that was newly taking shape. These changes gave Smetana hope that he would find suitable opportunities in Prague's musical life. Of course, the several years he spent abroad had distanced him from the domestic milieu, so he first of all had to re-establish personal and professional contacts at which he succeeded fairly quickly, and soon he began to participate intensively in musical and societal events. ${ }^{5}$ In this context, his change of linguistic orientation was also important. Previously, especially in writing, he had used German almost exclusively, having mastered that language because of his education in German schools, but he was conscious of the inadequacy of his knowledge of his native tongue, and especially as he entered into the circles of Czech society, he realised the necessity of improving his spoken and written Czech. ${ }^{6}$

Smetana's engagement in Prague's musical life in the first half of the 1860s took place on several levels in parallel. He was relatively active at the time as a journalist. In 1864/65 he wrote reviews regularly for the most important Czech newspaper Národni listy. ${ }^{7}$ In addition, in a few lengthier treatises he published his plans for the improvement of the city's concert life by giving philharmonic subscription concerts and his opinions about the mission and present condition of Czech opera with respect to dramaturgy, interpretation, and performance quality. ${ }^{8}$ Above all, Smetana engaged himself very intensively in the activities of associations, in which he had relatively broad opportunities, and especially at the beginning he significantly influenced the character of activities of institutions by

5 In early 1862 in Prague he gave two concerts by which he wished to introduce himself to the Prague public after his return from abroad, and that summer he took part in concerts held in several cities to raise money for building the National Theatre.

6 "Bei dem wiedererwachten Bewußtsein unserer Nationalität, ist es auch mein Streben, das Studium unserer schönen Sprache zu vollenden, um mich, seit meiner Kindheit nur an deutschen Unterricht gewöhnt, ebenso čechisch wie deutsch mit Leichtigkeit mündlich und schriftlich ausdrücken zu können." (With the reawakening of the consciousness of our nationality, I am also striving to complete my study of our beautiful language, so that I, having been accustomed to only German instruction since my childhood, shall be able to express myself with ease orally and in writing both in Czech and German.) Diary 1861/62 (December 1861), 9 (NM-MBS S 217/1099). From 1862 he began writing in Czech in his diary and most of his correspondence. Concerning the question of Smetana’s Czech, see Lucie Rychnovská, Čeština Bedřicha Smetany (Brno: Filozofická fakulta Masarykovy univerzity, 2019).

7 From May 1864 to April 1865 he wrote reviews mainly of opera performances (71), but also of concerts (19), and beginning in 1863 he also occasionally reviewed newly printed music (7). For a complete edition of all of Smetana's reviews and articles, see Václav Hanno Jarka, Kritické dílo Bedřicha Smetany 1858-1865 (Praha: Nakladatelství Pražské akciové tiskárny, 1948).

8 Bedřich Smetana, "O našich koncertech," Slavoj, October 1, 1862, 146-147; Bedřich Smetana, “Veřejný život hudební v Praze. I. Opera,” “Veřejný život hudební v Praze. II. Opera,” "Hudební poměry v Praze. Opera III,” Národní listy, June 24, July 15 and 22, 1864. 
his opinions and by taking concrete organisational and artistic steps. From 1863 to 1865 he was the choirmaster of the Hlahol singing society, with which he had been working since $1862 .{ }^{9}$ From that year, he also took part in preparing for the founding of the Artists' Society, the most important Czech arts society. He played a significant role in shaping the activities of its music department, having been its chairman in the early years (1863-1865). He also played an important part in several large-scale, prestigious projects which went above and beyond the scope of the society's events and which became extraordinary cultural events for Prague at the time. ${ }^{10}$

He apparently performed at least part of his public activities without entitlement to a fee-with a few exceptions, there is no documentation that he was paid for this work. ${ }^{11}$ This was mainly work for the causes of his country and of Czech music, or it was part of his activity in associations, but at the same time it was a matter of his artistic prestige and, undoubtedly, of personal ambition. Thanks to this wealth of activities, Smetana soon truly became one of the leading figures of Prague's musical life. Still, at no time during the first half of the 1860s did he gain a position of importance or social prestige that would also secure him a living. The position of first Kapellmeister of Czech opera at the Provisional Theatre, in which he showed an interest immediately upon his return from Sweden, ${ }^{12}$ was already taken at the time, in 1865 he was not selected as director of the Prague

9 Besides routine work as a choral conductor (rehearsals and concerts for the society), he attempted to extend the range of programming and interpretive possibilities of the society, which was relatively conservative in those days (he did not, however, succeed at establishing a women's choir and transforming Hlahol into a mixed choir). For more information, see Zdeněk Nejedlý, "Dějiny Pražského Hlaholu 1861-1911," in Památnik zpèváckého spolku Hlaholu v Praze vydaný na oslavu 50tileté ćinnosti, 1861-1911, ed. Rudolf Lichtner (Praha: Hlahol, 1911), 40-41, 45-53.

${ }_{10}$ In May 1864, near the time of the Feast of St John of Nepomuk, he conducted the main concert with several hundred performers for a major choral festival named after the saint and organised by Hlahol. He took part in planning the programming and as a performer and composer in the musical component of the grandly conceived celebration of the 300th anniversary of the birth of William Shakespeare in April 1864, by which the Artists' Society first presented itself to a wider public. At his initiative and under his direction, in the season 1864/65 it also gave three successful philharmonic concerts, but that could not be continued for financial reasons, and in 1866 it organised a grandiose performance of Liszt's oratorio Die Legende von der heiligen Elisabeth for which Smetana personally obtained the composer's permission. Concerning Smetana's activities with the Artists' Society, see Hanuš Jelínek, Padesát let Umélecké besedy 1863-1913 (Praha: Umělecká beseda, 1913), 80-108; Olga Mojžíšová, "Smetana and Shakespeare," Musicalia 9, no. 1-2 (2017): 57-59 (Czech), 68-71 (English); Olga Mojžíšová and Milan Pospíšil et al., Bedřich Smetana Correspondence II 1863-1874 (Praha: Národní muzeum, KLP, 2020).

${ }^{11} \mathrm{He}$ was undoubtedly paid for his work as a critic. As choirmaster of Hlahol he was entitled to a monthly salary, but he did not receive it and he declined a lump-sum fee in 1865 . Only a few fees for concerts are documented.

12 See Smetana's diary for 1861/62,13; Smetana's diary for 1862-1875, [15] (NM-MBS S 217/1099). 
Conservatoire, ${ }^{13}$ and his application for a state arts stipend was denied. ${ }^{14}$ Once again, the only way for Smetana to earn a living was by teaching music, and at a time when he was busy working on operatic projects, teaching increasingly became an unpleasant burden that kept him from his creative work. ${ }^{15}$

During his first two years in Prague, Smetana had almost no income, so he was living primarily from money from Sweden - at first there were the savings he brought back, then earnings from teaching and two concerts during a twomonth stay in Göteborg where he had gone in 1862 for financial reasons. There was also a loan from one of his closest friends from Göteborg, the merchant Isaac Philip Valentin, for Smetana's planned but not realised concerts in Vienna. This loan was never repaid. The partial achievement of financial security allowed the renewal of the musical institute in the autumn of 1863, but the balance for the first two years when Smetana was running the institute together with Ferdinand Heller was not entirely satisfactory and Smetana's budget continued to be suspect, particularly because of payments for the nearly 10-month visit and studies of his Swedish pupil Charlotte Valentin with him in Prague, followed by private lessons and lodgers in his flat.Even afterwards, when he himself was running the school, revenue was supplemented by private lessons, and in the first half of 1866 , it was the income from performances of his first two operas that finally helped him earn a steady living. ${ }^{16}$

In 1866 Smetana himself rehearsed and conducted the operas Branibori $v$ C $e^{-}$ chách (The Brandenburgers in Bohemia) and Prodaná nevěsta (The Bartered Bride) at the Provisional Theatre. ${ }^{17}$ Major changes to the theatre's administration, which was taken over that year by a Czech theatrical cooperative, ${ }^{18}$ and the successes of both operas contributed significantly to his appointment as the first

${ }^{13}$ For more, see Jan Branberger, Konservator̆ hudby v Praze (Praha: Konservatoř hudby v Praze, 1911), 80-90; Mojžíšová and Pospíšil et al., Correspondence II, 81-87.

${ }^{14}$ See Milan Kuna, "Žádosti Bedřicha Smetany o umělecké stipendium," Hudebni véda 25, no. 2 (1988): 120-131; Mojžíšová and Pospíšil et al., Correspondence II, 94-97.

15 Aleš Heller, "Vzpomínky Ferdinanda Hellera," in Vzpominky na Bedřicha Smetanu (Praha: Klub pensionovaných sólistů Národního divadla, 1917), 22.

${ }^{16}$ For information about Smetana's financial situation at the time, see Mojžíšová, "Die finazielle Lage," 20-23; Mojžíšová and Pospíšil et al., Correspondence I, II (letters to his wife Bettina and to I. P. Valentin from 1862-1864).

17 Their premieres were on January 5 and May 30, 1866.

${ }^{18}$ In the summer of 1866, the Austro-Prussian War interrupted the operation of the Provisional Theatre and ended the era of its German directors/entrepreneurs. Because there was no wealthy theatrical entrepreneur in Czech circles, the theatre came under the administration of a theatrical cooperative founded by twenty wealthy members of patriotically oriented circles, who invested their own money in its establishment. A succession of five cooperatives managed the Provisional Theatre. The turnover of these cooperatives was also in part a reflection of political interests that in turn influenced conditions in the theatre. 
Kapellmeister of Czech opera in September 1866. Thus he obtained one of the most important but also carefully scrutinised positions in Czech musical life; already while in Sweden he had had his eye on this position, and he retained it for eight years until he went deaf in 1874. As a consequence of the realities of theatrical practice, however, he had to back down from some of the ideas and demands he had formulated in print and to accept compromises related to the theatre's financial situation, the decisions of the theatre's administration, the need to accommodate the tastes and demands of the public, and operational limitations (a small orchestra and choir, a rather unstable ensemble of soloists, and the cramped premises of the Provisional Theatre). To satisfy a broad range of the public, Smetana's programming had to balance new works with familiar crowd-pleasers and serious works with lighter genres. He relied mainly on the proven Italian, French, and German repertoire, continually adding new titles, but he also increased the number of works by Slavic composers. Operetta also became firmly entrenched in the repertoire. The existence of the Provisional Theatre encouraged local composers, so under Smetana's leadership there were sharply rising numbers of new Czech operas ${ }^{19}$ Besides artistic matters such as programming and actual conducting, the positions of first Kapellmeister and from 1872 of artistic director of Czech opera also involved irksome administrative and organisational duties for the daily operations of the opera under rather unfavourable economic conditions, along with the routine schedule of rehearsals etc. Smetana did not have the talents of his predecessor Jan Nepomuk Maýr as a skilled administrator, taskmaster, and everyday conductor. Under Maýr, discipline at the theatre had been strict. Smetana tended to view ensemble members as his colleagues rather than as subordinates, and his attitude towards them was friendly and tolerant. According to period accounts, he approached the works being performed mostly from an overall perspective with a certain detachment and "generosity" regarding details. ${ }^{20}$ At the turn of the 1860s and 1870s, his

19 See Václav Štěpán and Markéta Trávníčková, Prozatímni divadlo 1863-1883 (Praha: Academia and Národní divadlo, 2006).

${ }^{20}$ See Heller, "Vzpomínky," 26: "Pochopení prováděných děl bylo skvělé - ale provedení nestálo na té výši. [...] Ideální kapelník kromě pochopení musí býti učitelem, musí míti i železné nervy i skálopevné zdraví k úmorným zkouškám (i jakousi zálibu v opravách, výcviku, vysvětlivkách atd.). A toho všeho - kromě pochopení - Smetana neměl. [...] byla to i jeho ostýchavost vůči umělcům, která mu bránila, aby poklesky sólistů, sboru i orchestru př́liš často opravoval. [...] Když můj otec Smetanu upozornil na nedostatky (chyby) jak sólistů, tak sboru i orchestru, odvětil tento: Nemám nikdy na mysli detaily, nýbrž celek - ducha skladby - proud myšlenek. Takové maličkosti (chyby) ztratí se v celku." (The grasp of the works being performed was wonderful - but the performing was not up to that level. [...] Besides understanding the music, the ideal conductor must also be a teacher, have nerves of steel, and have rock-solid health for the gruelling rehearsals (and must enjoy making corrections, drilling, giving explanations etc.). And-apart from understandingSmetana lacked all of this. [...] it was his timidity towards the artists that too often hindered him 
theatrical activities were also negatively impacted by disputes over the character and orientation of Czech opera largely in relation to opposing stances over Wagnerian principles of music drama which were dividing the Czech musical public at the time. Smetana's operas played an important part in these polemics. ${ }^{21}$ The disputes gradually afflicted other areas of musical life and turned personal, also reflecting political rivalries between the Old Czech and Young Czech parties. As a result, Smetana's work at the theatre became a target for indiscriminate attacks and criticism that directly threatened his position as first Kapellmeister.

Despite the demands of his work at the theatre, Smetana did not give up his other activities. He closed his musical institute in 1867, but for financial reasons he continued to teach privately until he lost his hearing. He limited his activities in associations somewhat, ${ }^{22}$ and he now appeared only rarely as a pianist, but his work as a conductor intensified. Besides occasional concerts, usually for various charitable or ceremonial purposes, he finally succeeded at realising his idea of giving philharmonic subscription concerts - he began regular series with the theatre orchestra from the season 1869/70, and he took part in them as a dramaturge and conductor until the season $1873 / 74 .{ }^{23}$

It was not until 1866 that artistic and creative work (conducting and composing) became the foundation of Smetana's income. Besides his salary from the theatre, which accounted for about half of his income, there were royalties from performances of his operas and one-off earnings from annual benefit performances. From then on, teaching represented only about one third of his income, and just one fifth from the 1870s. He supplemented these main sources of income with occasional lump-sum payments such as, for example, agent's commission for the sale of pianos. He also still had lodgers living and dining in

from correcting the lapses of the soloists, chorus, and orchestra. [...] When my father pointed out to Smetana the shortcomings (errors) of the soloists as well as of the chorus and orchestra, he replied: "What I have in mind is never the details, but instead the whole- the spirit of the composition-the flow of ideas. Such trifles (errors) get lost in the whole.")

${ }^{21}$ In particular, Smetana's third opera Dalibor (1868) was the target of polemics. It caused confusion and disappointment, and it was described as being too indebted to Wagner and as deviating from the ideals of Czech opera.

${ }^{22}$ He stepped down as choirmaster of Hlahol in 1865; he was still the chairman of the music department of the Artists' Society from 1868 to 1870, but other members took up the main initiative, and in the 1870s the department's overall level of activities decreased considerably; see Jelínek, Padesát let, 97-101.

${ }^{23}$ He presented them on his own initiative, independently of his work at the theatre. For this purpose, from the season 1870/71, he managed to engage members of the orchestras of the Czech and German operas, and from 1873 an orchestral society called "Filharmonia" that had been established for this purpose took over the presenting of the concerts and the conductors of the two opera orchestras alternated at the helm. For more information see Vladimír Lébl and Jitka Ludvová, “Pražské orchestrální koncerty," Hudebni věda 17, no. 2 (1980): 108-110. 
his flat, something that was rather usual in those days. Overall, throughout this period Smetana had a very stable, slightly above-average level of income: in the first half of the 1860s his annual income varied between 1,600 and 2,000 gulden, and from 1866 to 1874 between 2,500 and 3,600 gulden. His financial situation was therefore basically satisfactory, without any more serious setbacks or losses. ${ }^{24}$ His income was always secured from multiple sources, however, and that entailed a constant, strenuous burden on his time and energy.

Smetana's intensive public engagement and huge workload from 1862 to 1874 was strongly reflected in the amount of music he was writing and in its orientation. Immediately after his return from Sweden, his focus shifted to opera which was then regarded as the supreme artistic genre and there was demand for the creation of a Czech operatic style for the process of national emancipation in the area of culture. Smetana composed most of the five operas he wrote over the span of the next few years slowly, ${ }^{25}$ but not only because of the search for creative solutions; certainly to a large extent, his job duties and his other artistic work and engagement in associations interrupted smooth progress with composing. His other works are no longer numerous, and they almost exclusively reflect societal demand. Besides patriotic choruses ${ }^{26}$ in connection with the general flourishing of the choral music movement and partially with his engagement with Hlahol in Prague, he now wrote just a few minor orchestral works for very specific occasions. ${ }^{27}$ During this period, he did not devote himself at all to piano music or chamber works, which represent a more intimate aspect of his composing or to other genres.

Smetana went deaf in 1874 and had to cease his public activities. He lost his regular income from the theatre and from teaching, and once his hopes of

${ }^{24}$ For more information, see: Mojžíšová, “Die finazielle Lage,” 23-25, 39, 41.

25 The Brandenburgers in Bohemia (1861-1863), The Bartered Bride (1863-1866) (other versions from 1868,1869 and 1870 were primarily the results of external stimuli), Dalibor (1865-1868), Libuše (1869-1872, it remained unperformed until the opening of the National Theatre in 1881). On the other hand, following a long pause after the performance of Dalibor, in an attempt to respond to attacks with a new work, he wrote Dver vdovy (The Two Widows) within the span of just half a year (July 1873-January 1874).

${ }_{26}$ The large-scale concert choruses Trri jezdci (The Three Riders, 1862), Odrodilec I (The Renegade I, double choir, 1863) and II (solo quartet and choir, 1864), and Rolnická (The Peasant, 1868), the cantata for mixed choir and piano Česká piseñ (A Czech Song, 1868), and a smaller, occasional work titled Slavnostni sbor (Festive Chorus, 1870).

27 Overtures to the marionette plays Doktor Faust (Doctor Faust, 1862) and Oldrich a Božena (Oldřich and Božena, 1863) for New Year's Eve with the Artists' Society, Pochod k slavnosti Shakespearově (March for the Shakespeare Festival, 1864), Slavnostni predehra C dur (Festive Overture in C major) for the ceremonial laying of the cornerstone of the National Theatre (1868), music for the tableaux vivants Rybár and Libušin soud (The Fisherman and Libuše's Judgment, 1869) for a benefit concert in support of the completion of St Vitus's Cathedral. 
recovery had vanished, he and his family moved to the rural village Jabkenice to save money. ${ }^{28}$ His creative abilities remained undiminished, however, and his time and energy were no longer drained by other activities, so he concentrated fully on composing. It was only during this period that he first devoted himself simultaneously to all of the genres of his earlier music, creating serious works of surpassing quality. The tempo at which he worked and his creative productivity were enormously high especially in the 1870 s, and it was only in the 1880 s that the progression of his illness slowed him down. It was in a state of deafness that he created most of his greatest works. ${ }^{29}$ Through personal contacts and written correspondence, he stayed informed about musical events in Prague and elsewhere, and during this last stage of his life he continued to exert significant influence over them through his music. It was not until the latter half of the 1870s that Smetana's compositions began to be played much more frequently in Prague and in rural areas by both professionals and amateurs. Some of his works even found their way abroad. ${ }^{30}$ Smetana's increasing popularity was also reflected in the various honours accorded to him for his past activities and works. Some important performances of his compositions and anniversaries of important dates in his life assumed the character of a nationwide celebration accompanied by ostentatious ovations, honours, and financial gifts in his honour. ${ }^{31}$ It was first during this period, undoubtedly in part under the influence of his tragic per-

${ }^{28}$ Smetana's wife Bettina and their two daughters lived there with the family of his daughter from his first marriage, Žofie Schwarzová, from June 1875. Smetana moved there permanently in June 1876 when it became clear that he would not be returning to work at the theatre.

${ }^{29}$ Operas: Hubicka (The Kiss, 1875-1876), The Two Widows - 2nd version (1877), Tajemstvi (The Secret, 1877-1878), Čertova stèna (The Devil's Wall, 1879-1882); orchestral: the cycle Má vlast (My Country, 1874-1875, 1878-1879), Pražskýkarneval (Prague Carnival, 1883); the piano cycles Rêves (1875) and České tance (Czech Dances) I and II (1877, 1879); two string quartets: E minor "Z mého života" ("From My Life," 1876), D minor (1882-1883); choruses: Píseň na moři (Song of the Sea, 1876-1877), Sbory trojblasné pro ženské blasy (Choruses for Three Female Voices), the cantata Česká píseň (A Czech Song) in a version for mixed choir and orchestra (1878), Vèno and Modlitba (The Dedication, The Prayer, 1880), Naše piseñ (Our Song, 1883), and the song cycle Večerní pisně (Evening Songs, 1879).

${ }^{30}$ According to existing sources (programmes, correspondence, the foreign report column of the journal Dalibor), from 1877 to 1884 the works most frequently played abroad were the quartet From My Life (Hamburg, Weimar, Vienna, Meiningen, Magdeburg, Leipzig, Paris, Moscow, Milwaukee), the symphonic poems Vyšehrad (London, Budapest, Warsaw, Paris) and Vltava (The Moldau) (London, Glasgow, Hanover), and the overture and excerpts from The Bartered Bride (Chemnitz, Munich, Dresden, Stuttgart).

31 A benefit performance a few days after the successful premiere of Smetana's opera The Kiss (Nov. 14, 1876) was accompanied by the first such celebration, and there followed the 50th anniversary of Smetana's first concert appearance (Jan. 4, 1880) and the 100th performance of The Bartered Bride (May 5, 1882). During a two-day celebration there was an unveiling of a plaque commemorating Smetana in Litomyšl, his birthplace (Sept. 18-19, 1880), and there was also an especially ceremonial atmosphere at the first complete performance of My Country (Nov. 5, 1882). It was 
sonal circumstances, that Smetana won wide recognition and appreciation for his service to Czech music.

During the last decade of his life, Smetana became exclusively dependent upon his creative output for his living. The theatre continued to provide him with a modest but stable income; in exchange for his allowing them to perform his existing operas free of charge, the theatre paid him an annual salary of 1,200 gulden. For new works that he was to supply on a regular basis, he retained entitlement to receive royalties and benefit performances until he delivered his next opera. Within the limits of what was realistically possible, the theatre's management treated Smetana in a very accommodating manner, and in spite of financial difficulties of its own, it never changed its arrangement with him. ${ }^{32}$ This basic living was also supplemented by smaller payments for performances of some of his operas by other theatrical companies mostly outside of Prague, and later he received a pension from the theatre and fees for the publication of some compositions. Especially at the onset of his deafness and then in the 1880s, Smetana received significant support for his family budget in the form of special income from certain benefit concerts or opera performances and from gifts of money on special or ceremonial occasions. ${ }^{33}$

From the preceding brief outline of Smetana's artistic and societal endeavours, it is clear that his importance and unique standing in the context of Bohemia's or Prague's musical life in the latter half of the 19th century is characterised chiefly by its versatility: as a composer he created works that laid the foundation for modern Czech music, and at the same time he was a performing artistan excellent pianist, performer of chamber music, conductor and choirmaster, a respected pedagogue, and an erudite music critic. He also brought important stimuli to the activities of certain cultural institutions. To earn a decent living, he had to engage in several activities in parallel, and that meant a heavy workload and a lack of time for composing which he always regarded as his chief calling. For this reason, he did not compose all that much music, and what he did write can be put into just five categories (operas, orchestral works, chamber music, piano works, and vocal music). Smetana's public activities influenced not only

also in this final decade that Smetana received most of his honorary memberships from musical societies and other institutions.

${ }^{32}$ His requests for a higher salary were always rejected, but no limits were put on his pay and other income even when austerity measures including pay cuts were implemented. Smetana's salary was not increased to 1,500 gulden until after the definitive opening of the National Theatre in 1883 .

${ }^{33}$ For more information, see Olga Mojžíšová, “Čestné finanční dary Bedřichu Smetanovi," in Miscellanea z výroční konference České společnosti pro hudebni védu 2008. Fenomén mecenášství v hudebni kultuře, ed. Jitka Bajgarová (Praha: Česká společnost pro hudební vědu, Etnologický ústav Akademie věd České republiky, Nakladatelství Agora, 2010), 78-83; Mojžíšová “Die finazielle Lage,” 25-27, 40. 
the quantity of his compositions, but also to a large extent the choice of their subject matter and genres. And this was also reflected in their utility for concert and operatic performance, their publication in print, and therefore also in possibilities for their further performing and dissemination at home and abroad and, as a final result, their profitability.

In view of the preponderance of miniature compositions, piano music is the most abundant. Piano works were predominant in the 1840s and in the first half of the 1850 s, i.e., at the time when he was seeking and refining his creative style and asserting himself more as a pianist, but his public engagement was generally negligible. In Göteborg in the latter half of the 1850s, his societal and public activities greatly increased, and his compositions (also with respect to larger-scale orchestral works) were no longer so numerous. He managed to have a series of piano compositions published in the 1850s, but he still usually received no fee or he even had to pay part of the cost of printing himself. From the 1860s, Smetana put his creative potential primarily into demanding operatic projects. He only had limited capacity for compositions that could be used routinely for concert performance and that would also be most in demand with publishers (chamber music, piano pieces, vocal works, smaller orchestral compositions) at first because of his heavy workload and later because of his progressing illness. Furthermore, at the time when his public activities were the most intensive, he did not devote much attention to the promotion of his music. Whenever some of his works actually did get performances abroad, it was thanks to the initiative and efforts of others. ${ }^{34} \mathrm{He}$ also more or less neglected the publication of his compositions, and what actually was published in Prague was generally the result of external stimuli. ${ }^{35}$ Smetana began to take a keener interest in the publication of his works and possibilities for their performing and promotion abroad after he went deaf, when he was under pressure to earn a living. His illness limited him in business dealings, however, and he was largely forced to rely on the agency and help of

${ }^{34}$ Through his contacts, František Ladislav Rieger was already trying to get The Bartered Bride performed in Paris in 1869; see Mojžíšová and Pospíšil et al., Correspondence II, 247-248, 262-264, 284-285. It was thanks to Czechs employed at the Imperial Theatre in Saint Petersburg, namely the chief conductor Eduard Nápravník and the bass Josef Paleček, that the opera was performed there in 1871. The circumstances of a performance in Zagreb in 1873 were apparently similarthere were also Czech singers and other musicians working there and Smetana gave performances in Prague of several operettas by the director of the Zagreb opera Ivan Zajc, who was of Czech descent on his father's side.

35 The March for the Shakespeare Festival was published in 1864 in connection with a Shakespeare festival, and his concert etude Am Seegestade - Eine Erinnerung was published that same year by Joseph Proksch together with concert works by his other pupils as part of his school of piano playing. The Peasant and Festive Chorus were incorporated into a collection of quartets for male voices titled Hlahol (Em. Starý, 1869, 1871), and the publisher Hudební matice chose the piano vocal score of The Bartered Bride to launch its activities (1872). 
others. ${ }^{36}$ It should also be noted that he was never very practical-minded or skilled at business. He did manage to get most of his new works published, but only by Prague publishers and for fees that reflected limited domestic potential, although his exclusive contract with the publisher Fr. A. Urbánek in 1879-1880 brought an immediate, respectable increase to his income. ${ }^{37}$ Abroad, where he was moreover an unknown composer, he then had nothing to offer besides his operas, and his creative capacity was no longer sufficient for new compositions. ${ }^{38}$

\section{Conclusion}

Smetana was engaged in the modern-era musical life of his country and of Prague for approximately two decades, and that was during its early, difficult phase. He was far from being alone on the Czech music scene, but during this period he was undoubtedly the most prominent figure. His music surpassed by far the quality of most Czech music of the day, and already during his lifetime it began to be perceived quite spontaneously as the foundation for modern Czech music, and his musical style was also viewed as the national style. Smetana inspired other composers as well, but only later generations would bring successors who were his equal. Smetana's other activities also contributed significantly to the development of musical life, especially in the area of concerts and operatic performances. Far more than any of his contemporaries or successors, from the 1860s he linked his activities and composing to what was going on in society, and he consciously subjugated them to the current ideas of his time and to the needs of nascent Czech musical culture. As an artist with a European outlook, however, he also wanted to extend local musical horizons beyond the limitations of Czech provincialism to a level comparable with that of the surrounding countries. In any case, we may regard as something of an affirmation of his exceptionalness the fact that at the turn of the 1860s and 1870s it was Smetana and his works that became the

${ }^{36}$ Above all, it was his former pupil and devoted supporter Ludevít Procházka who tried to promote Smetana's music during his tenure in Hamburg and Dresden (1878-1883). Procházka was responsible for performances of some of Smetana's works there, including the opera The Two Widows (Hamburg, 1881), and he helped Smetana establish contacts with German publishers. See Jan Löwenbach, Bedřich Smetana a Dr Ludevit Procházka. Vzájemná korespondence (Praha: Umělecká beseda, 1914).

37 This involved, among other things, publication of the second series of Czech Dances for piano, duets for violin and piano titled $Z$ domoviny (From My Homeland), the cycle Evening Songs, and above all, four-hand piano arrangements and scores of the string quartet From My Life and of the cycle of symphonic poems My Country. In particular, the project of publishing the scores of $M y$ Country was of exceptional importance, but it also entailed great expense and risk for the publisher. Publication was not successfully completed until the mid-1890s.

${ }^{38}$ Concerning the publication of Smetana's compositions, see Mojžíšová “Die finazielle Lage,”31-34. 
subject of disputes over the character of Czech opera and, to a certain extent, over the functioning of certain other areas of the Czech music scene.

It was not, however, just artistic and social circumstances that influenced Smetana's activities and composing. Despite all of his great creative tasks and artistic struggles, Smetana also lived an ordinary life and he perceived its moments of happiness as well as of disappointment and sorrow with unparalleled intensity and sensitivity. His fate was not easy; he had to deal with several truly tragic events: in quick succession, three of his four children died at an early age as did his first wife later on, ${ }^{39}$ then at age 50 he went deaf, had to give up the work that had provided him with a steady living, and was suddenly also cut off from public events. His second marriage to Bettina Ferdinandiová (1860) was not very happy and for the rest of his life Smetana suffered emotionally. His worsening health problems also gradually complicated and slowed his creative output. It is especially in his late correspondence and diaries that we find expressions of disappointment, sorrow, and even hopelessness and desperation. In spite of this, he did not cease to have a positive outlook on life, nor did he give up hope, and this was also strongly reflected in his music. He projected autobiographical moments into some of his works, whether deliberately and programmatically, or inadvertently and more covertly. ${ }^{40}$ However, his personal problems and tragedies did not fundamentally affect his work. There is always a brightening, a purifying catharsis that gives new hope. Faith and hope are also the message of Bedrich Smetana-the man and the artist.

\section{Translated by Mark Newkirk}

${ }^{39}$ Gabriela (1852-1854), Bedřiška (1851-1855), Kateřina (1855-1856). Kateřina Smetanová was 32 years old when she succumbed to tuberculosis in 1859 while being brought from Sweden to Bohemia.

40 The immediate inspiration for Smetana's Piano Trio in $G$ minor was the death of his exceptionally musically gifted daughter Bedřiška. The autobiographical character of the string quartet From $M y$ Life is documented several times by Smetana's accounts of its programme. There are preserved written hints from which one senses that there is a personal statement contained in the String Quartet No. 2 as well, and some of his piano works (e.g., the cycles Bagatelles et Impromptus or Rêves) apparently also incorporate intimate personal moments. Smetana's last three operas also reflect the circumstances of his life to a certain extent. They were meant to be comic operas, but the comic element in them is softened. In all three operas, the more serious side of the story prevails, with themes of the authenticity and depth of human relationships and feelings, and deliverance into happy fulfilment through the forbearance and self-denial of the pairs central. It is as if Smetana projected into these stories his own sorrow from emotional disappointment as well as the hope he still maintained. 


\section{Bedřich Smetana: An Artist and a Man of His Times}

\section{Abstract}

Through his activities, Bedřich Smetana fundamentally influenced the formation of modern Czech musical life. The exceptional nature of his position lies in the breadth and versatility of his activities. As a composer, he founded modern Czech music and he asserted himself as a pianist, conductor, choirmaster, music teacher, and music critic. For eight years he was at the helm of the Czech opera of the Provisional Theatre and participated significantly in the establishment and activities of some of Prague's cultural institutions. Smetana's public endeavours and artistic efforts were closely related to societal events, especially from the 1860s onwards, and this linkage between artistic intentions and societal demand is reflected in his production in terms of the range and choice of themes and genres. To some extent, Smetana subordinated his personal life to his public activities and artistic vocation, and his financial situation also reflected this decision.

\section{Bedřich Smetana: umělec a člověk své doby}

\section{Abstrakt}

Bedřich Smetana svými aktivitami zásadně ovlivňoval formování novodobého českého hudebního života. Výjimečnost jeho postavení spočívá př́edevším v šírí a všestrannosti jeho působení. Svými díly položil základy moderní české hudby, uplatňoval se jako pianista, dirigent, sbormistr, hudební pedagog a kritik. Po osm let stál v čele české opery Prozatímního divadla a významně se také podílel na vzniku a činnosti některých pražských kulturních institucí.Jeho veřejné pưsobení i tvưrčí činnost byly zejména od 60 . let 19 . stol. těsně provázány s aktuálním společenským děním a toto propojení uměleckých záměrů se společenskou potřebou odráží rozsahem a volbou námětů a žánrů i jeho tvorba. Veřejnému působení a tvưrčímu poslání Smetana do značné míry podřizoval i osobní život, což se promítlo též do jeho ekonomické situace.

\section{Keywords}

Bedřich Smetana; musical life; 19th century

\section{Klíčová slova}

Bedřich Smetana; hudební život; 19. století 
This work is financially supported by the Ministry of Culture of the Czech Republic (DKRVO 2021/22.II.a, 00023272).

Olga Mojžíšová

National Museum Prague

olga.mojzisova@nm.cz 